\title{
Board Effectiveness and Stock Liquidity Empirical Evidence at the Nairobi Securities Exchange
}

\author{
David Magaki Bichanga*, Dr. Florence Memba, Dr. Agnes Njeru \\ School of Business and Entrepreneurship, Department of Economics, Accounting and Finance, Jomo Kenyatta \\ University of Agriculture and Technology, P.O. BOX 62, 000, 00200, Nairobi, Kenya. *Corresponding author \\ Emails: davemagaki@gmail.com,fmemba@jkuat.ac.ke, agnes1398@gmail.com
}

\begin{abstract}
The aim of this paper was to assess the influence of the board effectiveness on the stock liquidity of firms listed at the Nairobi Securities Exchange. The success of security markets highly depends on stock liquidity. The ease of buying and selling of securities in the stock market while not bringing any effect on the prices. Board effectiveness has been found to play a key role as an aspect of corporate governance on firms' financial performance but its role still remains unclear on stock liquidity of firms listed at the NSE. It is on this merit that this paper sought to fill the existing gap by establishing whether the board effectiveness influences stock liquidity of firms listed at the NSE. A census was carried out on all the 68 firms listed at the Nairobi securities exchange for the period spinning from 2014 to 2018. This study used secondary obtained from the NSE and the listed firms' published annual financial reports. Data analysis was done using descriptive and inferential statistics. Under descriptive statistics; mean, median, minimum, maximum, and standard deviation were used and for the inferential statistics correlation and regression analysis within panel data framework were used. Data was subjected to diagnostic tests with Eviews 7 as the main statistical tool of analysis. The findings of the study indicated that board effectiveness had positive and significant influence on stock liquidity of firms listed at the NSE when quoted spread was used as measure but no significant influence when measured by turnover, illiquidity and liquidity ratio. This study recommended that more monitoring needs to be done to enable firms to reduce transaction cost.
\end{abstract}

Key Words: Board Effectiveness, Stock Liquidity, Nairobi Securities Exchange.

DOI: $10.7176 /$ RJFA/12-10-12

Publication date:May $31^{\text {st }} 2021$

\section{Introduction}

\subsection{Background of the Study}

Effective corporate governance helps to build vibrant and efficient capital markets. Investor's confidence will be enhanced in market where firms have high standards of corporate governance. Corporate governance encompasses processes for board effectiveness and enhanced transparent disclosure of information. Both these requirements led to improved quality and quantity of information made available to investors. It can be assumed that information flow influences stock markets performance and results in informed trading, reduce information asymmetry and improve stock market liquidity.

In corporate world, the board is considered as the main driver of organizational effectiveness and its ability to achieve the expected goals. One of the major aspects of the board that plays a significant role in determining how well a company goes in meeting its mandate is the board effectiveness. Board effectiveness has attracted increased attention over the past years by legislators and investors as well. For instance, the Cadbury Report in the UK (1992) emphasized the need for the board of directors within listed firms to be effective and reviewed board structure as well as the responsibilities of the board's directors. The factors that determine the influence of the board effectiveness on stock liquidity are usually factors related to the board control and the quality of the process of decision making. Board effectiveness is only if operative goals were clearly articulated, however, boards effectiveness have never been empirically demonstrated because it relies on more than one factor (Solomon, 2013).

Board size of the board has been a subject of significant research in terms of its influence on stock performance, having been fuelled by prominent business failures of large firms such as Enron and Worldcom (Klein, 2009). It is argued that within a certain range, the larger the board, the more effective it is in its statutory duties of monitoring management (Sanda, Mikailu \& Garba, 2005). The boards' size and composition influences its ability to function effectively. Boards in Europe, (UK, Switzerland and Netherlands) tend to have a small board size (fewer than ten board members) while other countries have a larger board size between thirteen and nineteen members (Belgium, France, Spain, Italy and Germany). In Australia, board size has an average of seven members (Wan, 2010). Smaller boards have generally been considered to be more efficient in decision making (Yermack, 1996) and to promote 
better decisions making, governance codes often specify that the board should not be too large. While there may be no one size fit all recommendation for what constitutes an optimal board size, a board size of $8-10$ is often recommended. In consistent with recommendation of a firm board size of 10 directors.

According to Cascio (2004) boards of directors may vary significantly in size from small (5 and 7 members) to very large (30 or more) members. However, there was no consensus as to whether larger or smaller boards are better with respect to their performance. Effective board has to monitor, discipline and remove ineffective management team. Non-executives directors' should critically assess, approve and review the financial and operational decisions of executive directors (Fama \& Jensen, 1983). To ensure efficiency and good communication from the management team, the board to keep a certain periodicity in the meetings of directors.

Upadhyay, Bhargara \& Faircloth (2014) board committees improves the observation of the performance of individual directors and also reduce coordination and communication problems. A well- defined plan of board meetings and the publishing of reports give more confidence to stakeholders and reduces the asymmetry of information between them. The frequency of board meetings provide signals to the market, thus revising expectations of investors, increasing the trading volume of stock transactions (Jensen, 2000). Linking stock liquidity with board effectiveness, it was worth noting since frequent meetings and board independence determines how well and efficiently decisions are made. Closer monitoring of firms' operations by the board could reduce transaction cost.

\subsection{Statement of the Problem}

In the past two decades, many securities markets across the globe have been facing tremendous challenges with increased collapse of the markets, escalating delisting of the listed firms and fluctuations in stock prices. The aspect possessed a threat to the overall continuity of the stock markets. Boards' ineffectiveness have been largely criticized for the decline in shareholders' wealth and corporate failure in recent times. Boards have been in the spotlight for their inefficiency that had resulted to the firms' inability to trade large size quickly at low cost. Board ineffectiveness was assumed to have adversely affected some firms listed at the NSE been delisted and suspended from trading. Despite of corporate governance guidelines by the Kenya Capital Markets Authority, firms' inability to trade large size quickly at low cost perseveres. This paper therefore sought to evaluate the influence of board effectiveness on stock liquidity of the listed firms at the NSE.

\subsection{Objectives of the Study}

\subsubsection{General Objective}

The general objective was to investigate the influence of board effectiveness on stock liquidity of firms listed at the NSE.

\subsubsection{Specific Objectives}

1. To evaluate the influence of the board effectiveness on stock liquidity of firms listed at the Nairobi securities exchange.

2. To analyze the moderating influence of firm size on the relationship between board effectiveness and stock liquidity of firms listed at the Nairobi securities exchange.

\subsection{Research Hypotheses}

Ho1: Board effectiveness has no significant influence on stock liquidity of firms listed at the Nairobi securities exchange.

Ho2: There is no significant moderating influence of firm size on the relationship between board effectiveness and stock liquidity of firms listed at the Nairobi securities exchange.

\subsection{Scope of the Study}

The study covered the period spanning January 2014 to December 2018 . The choice of January 2014 as the starting point of this study was informed by the fact that this was after the introduction and implementation of the Capital Market Authority corporate governance guidelines in Kenya of 2002 and the great financial crisis of 2008 and the time period captures the activities after NSE automated its trading activities in 2012. 


\section{Literature Review}

\subsection{Agency Theory}

The agency theory has its origins in the in the organizational works of Mitnick (1973) and economical agency theory developed by Ross (1973). The principal - agent relationship originates when a principal hires agent to perform a service. The agents' presence a high level of information and the inability of the principal to monitor the efforts of the agents not to take advantage of this information asymmetry to enrich themselves demonstrates the importance of effectiveness of the board. Agency theory scholars (Jensen and Meckling, 1976; Fama and Jensen, 1983) argue that the board of directors has the power and legitimacy to exert control over managers and ensure that they act in the best interests of the firm's shareholders and other stakeholders. Effective boards (in terms of the alignment of directors' and shareholders' interests) to be more engaged to maintain the firm's competitive advantage and enhance firm stock liquidity. The study was anchored on the agency theory.

\subsection{Conceptual Framework}

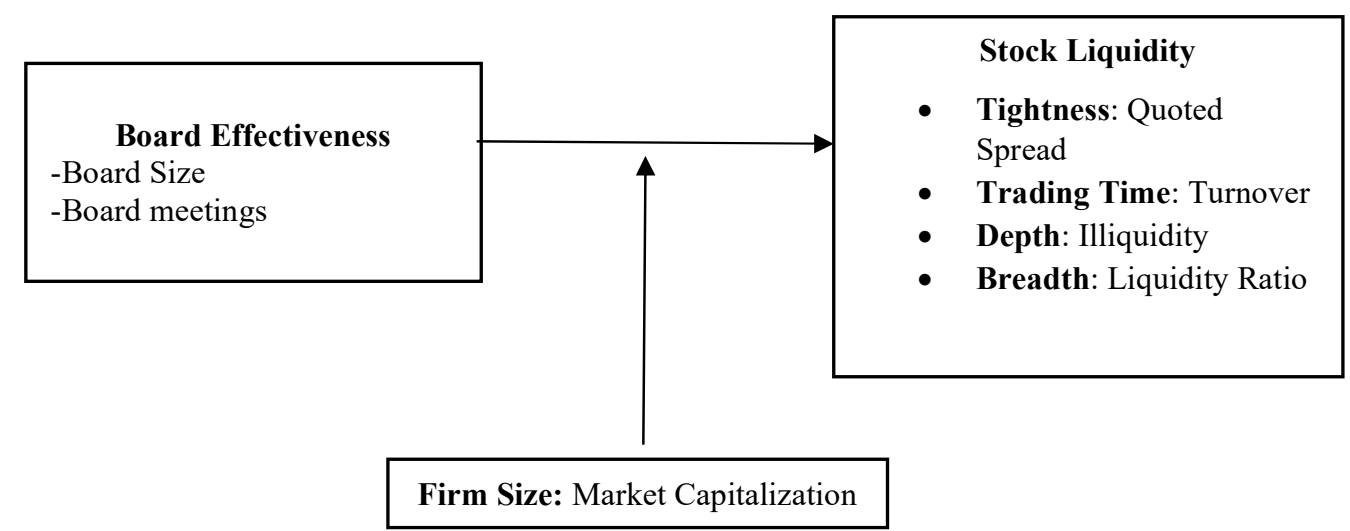

Independence Variables Moderating Variable

Dependent Variable

Figure 1: Conceptual Framework

\subsection{Empirical Review}

Sakwa (2015) investigated the effect of corporate governance on stock market liquidity of firms listed at NSE. The studies addressed the gap of whether the corporate governance variables had an effect on the stock liquidity and whether one can use them to predict the stock liquidity at the bourse. The population of the studies comprised of all the listed firms at NSE from the period of 2009 to 2013. The study adopted the independent variables of board of directors' size, board of director's independence, seniority of directors, frequency of board meetings and unitary structure of board. The dependent variable of stock liquidity were measured by; trading volumes, price volatility, share price and firm size. The study found that none of the variables were significant in predicating stock market liquidity.

The ANOVA test of significance on the five predictor variables found none of the variables to be of significance in predicating stock liquidity in the model. The study recommended that none of the selected corporate governance variables of firms at the NSE can be reliably used to project stock liquidity variations of listed firms. The nature of the relationship in terms of both magnitude and direction; an increase in board independence led to a sizeable increase in stock liquidity; an increase in board size led to a marginal increase in stock liquidity; the presence of unitary structure in the board led to a slight decrease in stock liquidity; an increase in slight decrease in stock liquidity; an increase in seniority of the board resulted in a marginal decrease in stock liquidity.

Wepukhulu (2016) researched on the relationship between corporate governance and performance of commercial banks in Kenya. The study conducted a survey on 43 commercial banks incorporated and were operating in Kenya during the period. The study used long term series data of 2001 to 2013. Corporate governance mechanisms were 
measured using selected internal corporate monitoring mechanisms of block ownership, institutional ownership, board independence and board size. The study used return on assets, return on equity and Tobin's q ratio as key variables that defined banks performance, whereas bank size was adopted as a control variable. The findings demonstrated that board independence was not significant in the relationship between corporate governance and performance of commercial banks when using return on asset, return on equity and Tobin's q. The study finding further revealed that bank size had a positive and significant effect in the relationship between corporate governance and performance of commercial banks when all three measures of performance were used. Return on equity was found to be the best measure of performance in the Kenyan banking sector.

\section{Methodology}

Survey was conducted on the 68 firms listed at NSE for period spanning from $2014-2018$. The choice of this data time series was informed by the fact that this was after the introduction and implementation of corporate governance guidelines and 2013 new prudential guidelines by central bank of Kenya (CBK, 2017). The period also captured the activities after NSE automated its trading activities in 2012. The descriptive research design was adopted as the best approach to fulfill the objectives of this study. This used secondary data obtained from the Nairobi securities exchange and the firms' published annual financial reports. Under descriptive statistics mean and standard deviations were used and inferential statistics the hypotheses tested through regression models, regression coefficients and P-values. Data analysis was done using descriptive and inferential statistics by the use of Eviews 7.

\subsection{Regression Model}

In order to establish the combined influence of the independent variables on the dependent variable, a linear model was used. Therefore the model for this study was consolidated as:

$\mathrm{Y}=\beta \mathrm{o}+\beta_{1} \mathrm{X}_{1}+\varepsilon$

Equation (i)

Moderating Variable Regression Model

The moderating variable in this study was firm size. To determine the presence of moderating effect, the OLS model was then compared with the MMR model. Equation (ii) shows the Ordinary Least Squares (OLS) regression equation model predicting $\mathrm{Y}$ scores from the first-order effects of $\mathrm{X}$ and $\mathrm{Z}$ observed scores.

$\mathbf{Y}=\boldsymbol{\beta}_{\mathbf{0}}+\boldsymbol{\beta}_{\mathbf{1}} \mathbf{X}_{\mathbf{1}}+\mathbf{Z}+\boldsymbol{\varepsilon} \ldots \ldots \ldots \ldots \ldots \ldots \ldots \ldots$ Equation (ii)

Equation (iii), the Moderated Multiple Regression (MMR) model was formed by creating a new set of scores for the two predictors (i.e. $\mathrm{X}, \mathrm{Z}$ ), and including it as a third term in the equation, which yields the following model:

$\mathbf{Y}=\boldsymbol{\beta}_{\mathbf{0}}+\boldsymbol{\beta}_{\mathbf{1}} \mathbf{X}_{\mathbf{1}}+\boldsymbol{\beta}_{\mathbf{4}} \mathbf{Z}+\boldsymbol{\beta}_{\mathbf{5}} \mathbf{X}_{\mathbf{1}} * \mathbf{Z}+\boldsymbol{\varepsilon} \ldots \ldots .$. Equation (iii)

Where:

$\mathrm{Y}$ is the Stock Liquidity

$\mathrm{X}_{1}$ is the Board Effectiveness

$\mathrm{Z}$ is the firm size (moderating variable)

\section{Results and Discussion}

\subsection{Descriptive Statistics}

The findings of this study on Table 1 revealed that quoted spread as a measure of stock liquidity reported an average of $4.83 \%$ with a maximum of $80 \%$ and minimum of $3.21 \%$ with a deviated of $6.21 \%$ on both sides of the mean. Turnover as measure of as a measure of stock liquidity, the findings indicated an average of $8 \%$ with a maximum of $72.67 \%$ and a minimum of $1.7 \%$ with a deviated of $15.37 \%$ on both sides of the mean. The standard deviation of turnover was relatively high to that of quoted spread by $9.09 \%$. Illiquidity (ILLQ) when used as a measure of stock liquidity of listed firms at the NSE, the findings indicated an average of illiquidity was Ksh8.66 with a maximum of Ksh40.42 and a minimum of Ksh6.40 which deviated on both sides of the mean by Ksh7.82.

Liquidity ratio (LR) as a measure of stock liquidity, the findings revealed that firms listed at the NSE reported an average liquidity ratio of 0.2587 with a maximum of 1.928 and a minimum of zero that deviated by 0.2644 on both sides of the mean. On average the proportion of NEDs in the board, the findings indicated an average of $44.54 \%$, a minimum of $25 \%$ and maximum of $69.9 \%$. The findings further indicated that independent directors constituted nearly $50 \%$ of the board size with standard deviation of $5.29 \%$. The descriptive statistics results indicated that the standard deviation was relatively low with stock liquidity measures of quoted spread, turnover and liquidity ratio of $6.21 \%, 15.37 \%$, and $26.44 \%$ respectively and highest with illiquidity over $100 \%$.

The adopted measures were indication that the internal corporate governance mechanisms of firms listed at the NSE were sufficient in assisting them to monitor and control the transaction costs. The maximum over $100 \%$ and 
the minimum of $6.21 \%$ implied that all other factors constant the trading cost variation was $6.21 \%$ and over $100 \%$. Given these results quoted spread suffered from the hereroskedesticity and high volatility when adopted as stock liquidity measure. The illiquidity emerged as the best measure of the influence of corporate governance on stock liquidity. A number of studies show that illiquidity was a reliable measure of price impact and stock liquidity (Hasbrouck, 2009; Goyenko, Holden \& Trzcinka, 2009; Karolyi, Lee \& Van Dijk, 2012).

Skewness coefficients revealed that board effectiveness, independence of directors and seniority of directors were skewed to the negative side (skewness coefficient $-2.888,-0.477$ and -0.980 ). These findings were in support of Uyaebo and Usman (2015) who demonstrated that stock liquidity in Nigeria was not normally distributed though it was positively skewed. These findings were in support of random walk hypothesis which stipulates that stock market returns responds to both positive and negative news and could explain its ability to trade large size quickly at low cost. All these values were far away from zero that means the variables were not normally distributed as indicated by Jarque - Bera staistics.

Table 1: Descriptive Statistics

\begin{tabular}{lcccccccc}
\hline & LR & ILLIQ & $\begin{array}{c}\text { Quoted } \\
\text { Spread }\end{array}$ & Turnover & BE & BS & BDEP & $\begin{array}{c}\text { Firm } \\
\text { Size }\end{array}$ \\
\hline Mean & 0.258 & 8.657 & 0.048 & 0.080 & 1.047 & 0.086 & 0.445 & 0.176 \\
Median & 0.185 & 6.400 & 0.032 & 0.017 & 1.041 & 0.062 & 0.454 & 0.034 \\
Maximum & 1.928 & 40.42 & 0.800 & 0.726 & 1.255 & 1.000 & 0.699 & 2.500 \\
Minimum & 0.000 & 1.080 & 0.000 & 0.000 & 0.079 & 0.000 & 0.250 & 0.000 \\
Std. Dev. & 0.264 & 7.817 & 0.062 & 0.153 & 0.129 & 0.152 & 0.052 & 0.347 \\
Skewness & 2.801 & 2.026 & 6.466 & 2.548 & -2.88 & 5.231 & -0.477 & 3.579 \\
Kurtosis & 15.37 & 7.230 & 74.39 & 8.889 & 22.42 & 30.93 & 6.362 & 17.34 \\
Jarque-Bera & 2269 & 421.9 & 6471 & 745.5 & 5047 & 1093 & 150.2 & 3157.6 \\
Probability & 0.000 & 0.000 & 0.000 & 0.000 & 0.000 & 0.000 & 0.000 & 0.000 \\
Sum & 76.32 & 2554 & 14.25 & 23.61 & 309.0 & 25.42 & 131.3 & 52.18 \\
Sum Sq. Dev. & 20.54 & 1796 & 1.134 & 6.943 & 4.927 & 6.867 & 0.822 & 35.54 \\
Observations & 295 & 295 & 295 & 295 & 295 & 295 & 295 & 295 \\
\hline
\end{tabular}

\subsection{Diagnostic Tests}

The diagnostic tests were conducted by the use of Eviews 7 econometric software including; Normality test, Hausman test, Multicollinearity test and autocorrelation test. This study used a combination of tests including: Levin, Lin \& Chu t*, Im, Pesaran and Shin W-stat, ADF - Fisher Chi-square and PP - Fisher Chi-square. These tests are among the widely used and influential (Liang, 2017). These tests were founded on the assumption that all series are non-stationary under the null hypothesis but accounts for heterogeneity in the autoregressive coefficient, which is assumed to change freely among the states. This study employed the use of $t$ - statistics, $p-$ value, $f$ - test and chi - square to arrive at conclusive inference. The $t$ - test was used to determine if there was a significant difference between the means of two groups, which may be related in certain features. The $\mathrm{t}$ - test was used for the purpose of hypothesis testing.

\subsection{Correlation Analysis}

The findings in Table 2 revealed that the correlation of quoted spread with each of the four proxies of corporate governance namely; board effectiveness (BE), independence of directors (BDEP) and board structure (BS) were not statistically significant at $5 \%$ level $(\mathrm{r}=.249, \mathrm{p}-$ value $=.686 ; \mathrm{r}=.209, \mathrm{p}-$ value $=.735$ and $\mathrm{r}=.050, \mathrm{p}-\mathrm{value}$ $=.936$ respectively). Implied that the correlation between each of these variables with quoted spread does not exist above and beyond the influence of firm size. Invariably meant the above corporate governance mechanisms had no influence on the quoted spread of firms listed at the NSE. The correlation between board effectiveness and firm size is about $\mathrm{r}=0.867$, which indicated that there was a positive relationship between the variables.

The correlation between independence of directors and firm size was $r=0.297$ and between independence of directors and quoted spread was $r=-.209$. The relationship between these variables was negative, which indicated that as firm size and quoted spread increased, board effectiveness decreased thus stock liquidity. These findings were similar with those found by Roulestone (2003) there was a negative association between bid ask spread and trading volume. This findings were in line with those of Kahuthu, (2017) that an increase in the spread had a negative influence on stock liquidity and firm performance. This findings corroborates with those of (Nadia, Abdelfattah, \& Jen, 2014) who illustrated that depth exhibits a strong negative correlation with insurance and investment companies and a strong positive correlation with pension funds. On the contrary, Searat, Benjamin $\&$ Jen (2015) found that corporate governance quality was positively correlated with firm size, implied that better governed firms were large and older. 


\begin{tabular}{lllllllll}
\multicolumn{6}{l}{ Table 2: Partial Correlation Analysis Results } \\
\hline & $\begin{array}{l}\text { Firm } \\
\text { Size }\end{array}$ & $\begin{array}{l}\text { Quoted } \\
\text { spread }\end{array}$ & $\begin{array}{l}\text { Turn } \\
\text { over }\end{array}$ & ILLQ & LR & BE & BDEP & BS \\
\hline Firm & 1 & & & & & & \\
Size & $\ldots$ & & & & & & \\
Quoted & .144 & 1 & & & & & \\
spread & .817 & $\ldots$ & & & & & \\
Turnover & -.482 & .527 & 1 & & & & \\
& .441 & .361 & $\ldots$ & & & & \\
ILLQ & .814 & .098 & -.577 & 1 & & & \\
& .094 & .876 & .308 & $\ldots$. & & & \\
LR & -.554 & -.033 & .591 & -.932 & 1 & & & \\
& .333 & .958 & .294 & .210 & $\ldots$ & & & \\
BE & .867 & -.249 & -.834 & .726 & -545 & 1 & & \\
& .057 & .686 & .079 & .165 & .342 & $\ldots$. & & \\
BDEP & .297 & -.209 & -204 & -.259 & .517 & .431 & 1 & \\
& .628 & .735 & .742 & .674 & .372 & .469 & $\ldots$. & \\
BS & .221 & -.050 & -.271 & .720 & -.868 & .150 & -807 & 1 \\
& .721 & .936 & .660 & .170 & .570 & .810 & 098 & $\ldots$ \\
\hline
\end{tabular}

*Correlation is significant at the 0.05 level $(2-$ tailed $)$

\subsection{Unit Root Test Board Effectiveness}

Unit root tests were conducted to test for stationary, a time series is stationary if a shift in time doesn't cause a change in the shape of distribution; unit roots are one cause of non - stationary. Board effectiveness was found to be stationary as documented on Table 3, at intercept and level I (0) because the Levin, Lin \& Chu t* had a probability value of 0.0000 which was significant at $5 \%$ level of significance. Therefore, the null hypothesis that board effectiveness had a unit root was rejected.

Table 3: Results on Board Effectiveness

\begin{tabular}{|c|c|c|c|c|}
\hline Method & Statistic & Prob.** & $\begin{array}{c}\text { Cross- } \\
\text { sections }\end{array}$ & Observ. \\
\hline $\begin{array}{l}\text { Null: Unit root (assumes common unit root process) } \\
\text { Levin, Lin \& Chu t* } \\
\text { Null: Unit root (assumes individual unit root process) }\end{array}$ & -9.3949 & 0.0000 & 46 & 184 \\
\hline $\begin{array}{l}\text { Im, Pesaran and Shin W-stat } \\
\text { ADF - Fisher Chi-square } \\
\text { PP - Fisher Chi-square }\end{array}$ & $\begin{array}{r}-2.0980 \\
98.032 \\
103.58\end{array}$ & $\begin{array}{l}0.0180 \\
0.3141 \\
0.1924\end{array}$ & $\begin{array}{l}46 \\
46 \\
46\end{array}$ & $\begin{array}{l}184 \\
184 \\
184\end{array}$ \\
\hline
\end{tabular}

\subsection{Regression Results}

Hausman test was conducted to test the hypothesis that there was no influence between the dependent variable of quoted spread and the predictor independent variables: board effectiveness, independence of directors, board structure and seniority of directors while moderating the influence of firm size. The test results were as per Table 4 , indicated that the Chi-square test statistic was 4.75406 with an insignificant $p$ - value of 0.447 . This therefore meant that the null hypothesis was rejected in favor of the random effects model. Therefore, the random effects model was accepted as suitable for this equation. 
Table 4: Hausman Test Results on Quoted Spread

\begin{tabular}{lrrrr}
\hline Test Summary & & Chi-Square Statistic & $\begin{array}{r}\text { Chi-Square } \\
\text { Difference }\end{array}$ & $\begin{array}{r}\text { Probability } \\
\hline \text { Cross-section random }\end{array}$ \\
Cross-section random effects test comparisons: & & 4.75406 & 5 & 0.447 \\
Variable & Fixed & Random & Variable (Different) & Probability \\
Board Effectiveness & 0.04462 & 0.08032 & 0.00099 & 0.256 \\
Independence of Directors & 0.02723 & 0.09173 & 0.00334 & 0.265 \\
Board Structure & -0.01610 & 0.00022 & 0.00018 & 0.218 \\
Seniority of Directors & -0.01743 & -0.09317 & 0.05049 & 0.736 \\
Firm Size & 0.00242 & 0.02433 & 0.00118 & 0.524 \\
\hline
\end{tabular}

Table 5 indicated that board effectiveness had $r=0.08$ and a significant $\mathrm{p}$ - value of 0.010 which was significant at 5 percent level of significance. This meant that when board effectiveness increased by 0.08 percent per year then tightness increased by 1 percent in the same year. Independence of directors had $r=0.09$ and an insignificant $p$ value of 0.2002 . This meant that independence of directors had no significant influence on tightness during the study period. Independence of directors had a positive but insignificant relationship. Board structure had $\mathrm{r}=0.00022$ and an insignificant $\mathrm{p}$ - value of 0.993 . This meant that board structure had no significant influence on tightness during the study period. Board structure had a positive but insignificant relationship.

Seniority of directors had $r=-0.09$ and a significant $\mathrm{p}$ - value of 0.016 which was significant at 5 percent level of significance. The coefficient of seniority of directors was negatively significant. This suggests that improved corporate governance was inversely linked with trading cost dimension of stock liquidity. This meant that when seniority of directors decreased by 0.09 percent per year then tightness increased by 1 percent in the same year. Firm size had $r=0.02$ and an insignificant $\mathrm{p}$ - value of 0.057 . This meant that firm size had no significant influence on tightness during the study period. Firm size had a positive but insignificant relationship. The constant had $\mathrm{r}=0.004$ and an insignificant $\mathrm{p}$ - value of 0.944 . This meant that jointly these proxies of corporate governance did not influence tightness as a measure of stock liquidity during the period of study.

The regression were not well fitted with an adjusted R- squared of 3.5\%. The $\mathrm{R}$ - squared value implied that there was $3.5 \%$ less variation around the line than the mean, in other words, the relationship between quoted spread and corporate governance accounts for $3.5 \%$ of the variation. The R- squared results were very low. The R- squared was interpreted as the fraction of the variance of the dependent variable explained by independent variables. The Durbin - Watson statistic for quoted spread was 1.39466. The study findings were similar to those of (Baum \& Christopher, 2006), who concluded that the acceptable range of Durbin - Watson should be within 1.50 - 2.50. Since the Durbin - Watson statistic for this study was within the acceptable range there was no concern for autocorrelation.

Table 5: Random Effects Model on Quoted Spread

\begin{tabular}{|c|c|c|c|c|}
\hline Variable & Coefficient & Standard Error & t-Statistic & Probability \\
\hline Board Effectiveness & 0.08032 & 0.03107 & 2.58510 & 0.010 \\
\hline Independence of Directors & 0.09173 & 0.07145 & 1.28386 & 0.200 \\
\hline Board Structure & 0.00022 & 0.02340 & 0.00928 & 0.993 \\
\hline Seniority of Directors & -0.09317 & 0.03827 & -2.43437 & 0.016 \\
\hline Firm Size & 0.02433 & 0.01273 & 1.91079 & 0.057 \\
\hline \multirow[t]{3}{*}{ Constant } & 0.00378 & 0.05360 & 0.07046 & 0.944 \\
\hline & \multicolumn{2}{|c|}{ Effects Specification } & & \\
\hline & & & $\begin{array}{l}\text { Standard } \\
\text { Deviation }\end{array}$ & Rho \\
\hline Cross-section random & & & 0.0245 & 0.166 \\
\hline Idiosyncratic random & & & 0.0550 & 0.834 \\
\hline \multicolumn{5}{|c|}{ Weighted Statistics } \\
\hline R-squared & 0.05141 & Mean dependent variable & & 0.03422 \\
\hline Adjusted R-squared & 0.03499 & S.D. dependent variable & & 0.05592 \\
\hline S.E. of regression & 0.05493 & Sum squared residual & & 0.87210 \\
\hline F-statistic & 3.13252 & Durbin-Watson stat & & 1.66115 \\
\hline Probability (F-statistic) & 0.00904 & & & \\
\hline \multicolumn{5}{|c|}{ Unweighted Statistics } \\
\hline R-squared & 0.08478 & Mean dependent variable & & 0.04831 \\
\hline Sum squared residual & 1.03875 & Durbin-Watson stat & & 1.39466 \\
\hline
\end{tabular}




\section{Conclusion}

The study concluded that board effectiveness had positive and significant influence on stock liquidity of firms listed at the NSE when quoted spread was used as measure but no significant influence when measured by turnover, illiquidity and liquidity ratio. The size of the board was found to be a factor in the effectiveness of the board. Small board are effective because it is easy to coordinate and tends to be more cohesive. The study further concluded that firm size had a positive and an insignificant $\mathrm{p}<0.05$ with quoted spread. This implied that firm size had no significant influence on tightness during the study period and had a positive but insignificant relationship. Firm size had negative and an insignificant $\mathrm{p}<0.05$ with turnover. This means that firm size had no significant influence on trading time during the study period and had a negative but insignificant relationship. Frequent board meetings enables the board to draw closer to the firms' operations. Board effectiveness enables firms to trade large size quickly at low cost. This study concentrated only on the influence of board effectiveness on stock liquidity of firms listed at the NSE. Based on the finding of this study the capital market authority as a regulator should have a seat in the boards of all firms listed at the NSE. Future researchers to focus on firms operating outside the NSE and investigate the influence of board effectiveness on financial performance using differ measures as such ownership structure, nomination, audit and remuneration.

\section{References}

Cadbury Report. (1992). Report of the committee on the financial aspect of corporate governance. London: Gee Publishing.

Cascia, F., (2004). Board governance: A social systems perspective. Academy of Management Executive, 18(1), pp. $97-100$.

CBK. (2017). Prudential guidelines 2017. Nairobi: Central Bank of Kenya. Retrieved from https://www.centralbank.go.ke

Fame, E., \& Jensen, M., (1983). Separetion of ownership and control. The Journal of Law and Economics, 8 (1), $301-326$.

Goyenko, Y., Holden, W., \& Trzcinka, A., (2009). “Do liquidity measures measure liquidity?” Journal of Financial Economics, 105, $82-112$.

Hasbrouck, J., (2009). "Trading costs and returns for us equities: Estimating effective costs from daily data". The Journal of Finance, 64, 1445 - 1477.

Jensen, M. (2000). Theory of the firm: Governance, residual claims and organizational forms. Boston: Harvard University Press.

Jensen, M., (1993). "The modern industrial revolution, exit and the failure of internal control systems". Journal of Finance, 48, pp. $831-880$.

Jensen, M, \& Meckling, W., (1976). "Theory of the firm: Management behavior, agency costs and ownership structure". Journal of Financial Economics, 3 (4), pp. 305 - 360.

Kahuthu, W., (2017). The effect of stock market liquidity on stock returns of companies listed on Nairobi securities exchange (Thesis). Nairobi: Strathmore University. Retrieved from http://suplus. Strathmore.edu/handle/11071/5594.

Karolyi, G., Lee, K., \& Van Dijk, M., (2012). “Understanding commonality in liquidity around the World”. Journal of Financial Economics, 105, $82-112$.

Klein, H., (2009). Principal - agent problems in the financial crisis of 2007 -2009. Unpublished Maters' Thesis, Amsterdam: Vrije Universiteit.

Liang, D. (2017). Introduction to Java Programming and Data Structures, Comprehensive Version (1 $11^{\text {th }}$ ed.), London: Oxford University Press.

Mitnick, B., (1973). Origin of theory of agency: an account by one of theory's originators. SSRN 10203782019 papers.ssrn.com.

Nadia, B., Abdelfatteh, B., \& Jean, P., (2014). "Corporate governance and market microstructure: Evidence on institutional investors in the Tunisian stock exchange", International Journal of Academic Research in Accounting, Finance and Management Sciences, Vol. 4, No. 2, pp. 62 -75.

Ross, S., (1973). “The Economic Theory of Agency: The principal's problem”. The American Economic Review, JSTOR.

Roulstone, T., (2003). “Analyst following and market liquidity”. Contemporary Accounting Research, Vol. 20 No. 3, pp. $551-578$.

Sakwa, B., (2015). The effect of corporate governance practice on stock market liquidity of firms listed at the Nairobi securities exchange. Master's Project, University of Nairobi.

Searat, A., Benjamin, L., \& Jen, S., (2015). Corporate governance and stock liquidity. Griffith University Australia. 
Sanda, A., Mikailu, A., \& Garba, T., (2005). Corporate governance mechanisms and firm performance in Nigeria. African Economic Research Consortium, Research Paper 149.

Solomon, J., (2013). Corporate governance and accountability. London: John Wiley \& Sons

Upadhyay, A., Bhargara, R., \& Faircloth, S., (2014). Board structure and monitoring committees. Journal of Business Research, 67, $1486-1492$.

Uyaebo, S., \& Usman, F., (2015). “Application of Asymmetric GRACH Models”. Journal of Applied Statistics, $134-160$.

Wan, F., (2010). Characteristics of Board of Directors and Board Effectiveness: A study of Malaysian Public Listed Companies: Victoria University: PhD Thesis.

Wepukhulu, J., (2016). Relationship between corporate governance and performance of commercial banks in Kenya. Nairobi, Kenya: PhD Thesis, Jomo Kenyatta University of Agriculture and Technology (JKUAT).

Yermack, D., (1996). Higher Market Valuation of Companies with Small Board of Directors. Journal of Financial Economics, 40, 185 - 211. 